\title{
BEGINNING OF MEDICINE HISTORY STUDY IN TURKEY: EDUCATION AND PUBLICATIONS
}

\author{
M. Zhbannikova, K. Milenkaya \\ Southern federal university, State public institution of Rostov region. \\ Rostov-on-Don, Russian Federation \\ science-almanac@mail.ru
}

\begin{abstract}
Globalization processes significantly increase in the modern world, the scientists more often deviate from regional researches to more extensive territorial researches, comprising not only the region of their habitation. Black Sea region - the territory, which originally was a centre of a highly developed culture, science and medicine. An attempt to give historiographic review of researches, produced mainly in Istanbul in the period from the end of XIX century, when the first publications appeared according to the theme of Turkish medical history, and to the first part of XX century is undertaken in the given writing, dedicated to medicine history in Turkey. The subject matter is formation, historical evolution and the modern state of medicine history in Turkey, predominantly in Istanbul. The problems of medicine history teaching touched upon in Turkey, connected with language and linguistic peculiarities, creation of dictionaries, which helped to use the basic medical terms and conceptions. It is shown how medicine history education in Turkish language and also history of development and formation of this process were important for the students and listeners. The emersion of Turkish books on medical history, as of Turkish authors (for instance, Mekhmet Emin Fekhmi), so the translated writings (Huseyin Ramsey - "Tarih-i Tıb") is very significant. It is interesting that even the workers of various Istanbul hospitals could be the authors of the books. The first years of XX century were marked by the works, where the researches of medical historical societies (Rysa Tahsin - "Mirat-i Mektebi Tıbbiye") were described. The works on Turkish medicine history were actively developed in 20-s of XX century under conditions of young Turkish republic formation. The challenges in the given work are: to generally consider the biographies of outstanding Turkish medicine historians and their writings, wrote in the first part of XX century, which contributed to Turkish science.

Key words: Medicine history, Turkey, Turkish historical society, Turkish medical historical society, Kyrymly Aziz, Mekhmet Emin Fekhmi, Rysa Tahsin, Galip Ata, Sukheil Unver.
\end{abstract}

Recently, researches, dedicated to various history aspects: routine, gender researches, history of technique, music, medicine and etc. became more topical. History of medicine is significant not only for its theoretical base for the humanitarian researchers, but also practical constituent for medical personnel. The object of research is writings on medicine history, wrote by Turkish researches from the end of XIX century, when the first publications on medicine history of Turkey appear, to the first part of XX century. Genesis, development and modern state of medicine history in Turkey appear to be the subject matter. The degree of the scientific development of the given problematics should be noted. Thus, a great number of researches, dedicated to various aspects of medicine history exist in the Turkish historiography. Türk Tarih Kurumu [8] (Turkish historical society) and Türk Tıp Tarih Kurumu [10] (Turkish medical historical society) significantly contributed to the given theme study. Besides, Uluslararası Türk Tıp Tarihi Kongresi (International Turkish historical congress), are annually carried out from 1990, which publish sourcebooks according to the results of conference [9]. Moreover, it is important to emphasize that resumptive works of Turkish authors on medicine history exist, for instance, the work of Ali Khaidar Baita, published in 2016 deserves special attention [2]. Certainly, within the given 
publication, it is impossible to analyze all of them, however, it is planned to give the general historiographic review of the problem. The aim of the work is concluded in complex research of medicine history formation in Turkey as science and activity of the most outstanding scientists in this sphere. The following challenges are set for this:

At first, to consider biographies of the outstanding historians of medicine and their writings, wrote in the first part of XX century. Secondly - to retrace connections between medicine historians and historians, the interests sphere of whom is not directly connected with medicine, but, nevertheless, appears to be an integral part of researches on historical studies. The article represents the complex research, generalizing varied empirical material. Consistency principle is considered to be the methodological basis, in accordance with which the writings of Turkish medicine historians are analyzed from the end of XIX - first part of XX century from one side, and their general and particular features are emphasized in comparison with works of European authors, from the other side. Historicism principle is laid at the basis of analysis of history medicine genesis in Turkey, permitting to consider this scientific phenomenon in the processes of its emersion and development, in connection with specific circumstances generated it. The analysis of written sources is realized with appliance of comparatively-historical analysis method. It allowed opening of the researched phenomena essence, identify the general and regular, from one side, and qualitatively different, - from other side. The given method afforded ground to come to wider historical generalizations and parallels. The authors along with general scientific cognition methods: qualitative, informative analysis, descriptive analysis, and also inductive and deductive method, applied specially-historical methods (chronological, comparatively- historical, genetic, typological, retrospective), with which tried to reach more complete solving of the challenges.

The sources complex, created at the end of XIX - first part of XX century, reissued in modern Turkish language, served as Source basis for study of historians activity in medicine. Speaking about emersion of such directions, as medicine history, it should be noted that one of the first lessons according to this theme on the basis of Mekteb-i Tıbbiye-i Şahane (later medical department of Istanbul University) was led by doctor Charles Edwards, the participant of Crimean War, who came to Turkey. Then, from 1860 to 1863 history of medicine was taught by doctor Zoeros Pasha (1841/44-1917) [7]. Gradually, the new theme finds its worshippers, and in the end of 1860-s the interest to medicine history grows, as number of those, who want to study medicine history in native language. And there one should touch the history of Turkish language and problems of Turkic languages classification and the modern Turkish language origin. Considering, historical aspect, all modern Turkic languages are divided into two branches: West Hunnic and East Hunnic [11]. To the first one can refer Oguz group of languages, from which the modernTurkic language appeared. The Turkish language development is divided into 4 periods: Old Turkic period (before XIII century of A.D.), middle ages period (to XV century), Ottoman period (XV-XIX century) and modern period. The Turkish language consists as of Turkic words, so of borrowed words - Armenian, Greek, Slavic, English, German, French. The most part of the words has Arabic and Persian origin. Arabic and Persian grammatical forms penetrated to the Turkish language through religion and literature; the Persian Language also influenced on syntax [12; 13, p. 7].

The norms and rules of the modern Turkish language began to form after the Kemalist revolution and republic formation. Before 19233 styles on spoken language existed under the influence of archaic letter forms: 1. Kaba Türkçe (tough Turkish language), the language in which the basic part of rural population spoke, 2. Orta Türkçe (middle Turkish language) - language of citizens. 3. Fasıh Türkçe, literary language till the middle of XIX 
century, full of foreign borrowings [13, p. 7]. The education was conducted in French language in medical schools that was a serious barrier for the Turkish students, and a number of graduates was not too large. This problem became more vital and should have found its solving. That is why it was very important for young doctors to prove the significance of medical education obtaining in Turkish language. Absence of special TurkishFrench dictionaries also complicated the Education in French language. Turkish medical men decided to translate dictionary of Pierre Hubert Nysten (1771-1818) to Turkish language. The Dictionary of Nisten "Nouveau dictionnaire de médecine, de chirurgie, de pharmacie, des sciences accessories et del'art vétérinaire" [14] was especially helpful in dictionary training, as descriptions of the basic medical terms and conceptions, were contained in it. The first edition of 1810 was republished 12 times that emphasizes its popularity and importance. Tenth edition contained supplements of the Latin, Greek, German, English, Italian and Spanish synonyms and glossary in these languages. The Latin and Greek dictionaries came into the last edition. Turkish redactors used oldturkic words and new concepts, formed with the help of Arabic borrowings, to find correspondence between French medical terms and Ottoman language. This dictionary was published in Istanbul in 1873 under the title "Lugat-ı Tıbbiye/Des Sciences Medicales Français-Turc" (FrancoTurkish medical dictionary). The articles, entered into this dictionary, contained not only information on history, but also the information on consecutive knowledge areas. One of the active participants of the group, working on the dictionary, doctor Kyrymly Aziz (18401878) gave the brief description of chemistry history at 68 pages of the article, which he called "Kimya-i Tıbbi" (chemical medicine) that can be considered as the first corresponding text in the Turkish language.

The first work in the Turkish language, dedicated to medicine history is written by doctor Mekhmet Emin Fekhmi in 1870, consists of 88 pages and called "Hakayık-ı Tababet" (Medicine facts). People, who did not believe in medicine as a science, and also those who support traditional medicine were rigidly criticized in the works of mentioned authors. One more book dedicated to history of medicine "Aperçu historique sur la medicine arabe" (Historical review of Arabic medicine) was published in this period in 1876 in Istanbul. The workers of various Istanbul hospitals and the lecturer of medical ethics under the medical department of Istanbul university Ottoman doctor losif Nurudzhan (born 1827) acted as redactors. The doctor Husein Ramsey (1823-1896) was one of the outstanding representatives, supporting medical education in the Turkish language. He is the author of the work "Tarih-i Tıb" (History of medicine), comprising the period from antiquity to roman (of Greek origin) medical man, surgeon and philosopher Galen (129/131-200/217), which actually was a translation "Histoire de la medicine depuis son origine jusqu`a XIXieme siècle" 1846 of Pierre Victor Renoir (born 1789).

The first years of $X X$ century were not marked with significant events in the medicine history. The book of doctor Rysa Taksin (1875-1950) "Mirat-i Mektebi Tıbbiye" (The doctor's mirror) deserves attention, as researches of medical historical societies firstly were described there. Two monumental scientific historical writings were created by mathematician Salikh Zeki (1864-1921): five-volume edition "Asar-ı Bakiye" and 11 volumes "KamusI Riyaziyat" (Mathematical sea). "Asar-ı Bakiye" is dedicated to the history of mathematics and astronomy and published in 1913. The manuscript of this book is stored in the library of Istanbul University. "Kamus- I Riyaziyat" - encyclopedia, containing information about mathematical theories and life of celestial bodies. The specified works of Salikh Zeki represent the ideas collection of medieval Islamic mathematicians and astronomers and European historians [3]. 
The medicine history works in 20-s of XX century are focused on history of Turkish medicine. Osman Shevki Uludag (1889-1964) and Galip Ata (1879-1947) rather antagonistically referred to all European and developed Muslim-Turkish science that found the most positive response under the conditions of young Turkish Republic formation. But from the other side, thoughts of medieval Arabic and Persian doctors, perceived even indirectly through translations of European medicine historians, were gathered gradually. Doctor Galip Ata greatly contributed to the development of the Turkish science. His book "Tıp tarihi" (Medical history), wrote in 1925, represents translation of European sources and composed according to standard scheme: describes Indian, Tibetan, Chinese and Far Eastern medicine, and "Tıp Fakültesi" published in the same year is dedicated to medical societies and medical education in Turkey [5]. Besides, Galip Ata translated "Introduction to experimental medicine study" of Claude Bernard to the Turkish language [4].

The next researcher to speak about was a person, the significance of whom for medicine history barely can be overestimated. Doctor Sukheil Unver (1898 - 1986) - the founder of medical department of Istanbul University, and also courses on history of medicine and medical ethics. He was interested in various aspects of the Turkish culture, but the basic part of his time he dedicated to researches and publications. More than 2500 of works on medicine history, science and culture are belonged to him, and the modern Turkish authors are concerned with his bibliographic heritage [1]. According to univerologists Uygur Tıbbı (Uigur medicine) and Selçuklu Tıbbının tarihi (Medicine history of Seljuks) published respectively in 1936 and 1943 are referred to the most significant works of Sukheil Ubver, where he tried to prove the Turkic origin of Ibn-Siny, Rasi, Biruni and Farabi.

Creation of Türk Tıp Tarihi Kurumu (the Turkish medical historical society) and editorial activity of Sukheil Ubver in 1935-1943 in the first Turkish medical historical journal Tıp Tarihi Arkivi became one more doubtless achievement of Sukheil Ubver, which brought him deserved respect and memory of descendants. Doctor Feridun Nafiz Uzluka (1902-1974), who as Unver created the school of medical history, but already in Ankara, was a friend and companion of Sukheil Unver. One more significant researcher doctor Adnan Adyvar (1882-1955) is famous for his work "La Science chez les Turcs Ottomans" (Science of Ottoman Turkish people) (Paris, 1938). Aidan Saiyly is famous for creation of the first scientifically-historical society in Turkey and therefore contributed to the development of the country medical education.

It is difficult to highlight the activities of all Turkish medicine historians of the pointed period within the frameworks of the article, only the most outstanding researchers are emphasized, whose activity was connected first of all with Istanbul and development of this significant theme in the Turkish society. It should be noted that quality leap in the given sphere occurred in the period between 1930-1950 and significantly promoted the Turkish science in the given sphere.

\section{Лumepamypa}

1. Ahmed Güner Sayar. A. Süheyl Unver, Hayatı, Sahsiyeti ve Eserleri 1898-1986, Eren Yayıncılık, İstanbul, 1994.

2. $\quad$ Ali Haydar Bayat. Tıp Tarihi. Pınarbaş Matbaacılık Ltd. Şti., Istanbul, 2016.

3. Celal Saraç.Salih Zeki Bey. Hayatı ve Eserleri. Ed. Yesim İsil UIman, İstanbul, Kizil Elma Yay. 2001. 
4. Değer M. Dr. Galip Ata Ataç ve Tıp tarihine hizmetleri.II Türk ve Tıp tarihi kongresi. Kongreye sunulan bildililer, İstanbul, 20-21 Eylül 1990. Türk Tarih Kurumu Yayınları.

5. Gülay Yıldırım, Selim Kadıoğlu, İlter Uzel.Galip Ata Ataç`ın «Tıp Fakültesi» kitabında yer alan Osmanlı Dönemi Tıp Eğitimi tarihçesi bilgileri. Cumhuriyet Üniversitesi. Tıp Fakültesi dergisi 29 (4), 2007, s. 185-191.

6. Gülbün Mesara, Aykut Kazancıgil, Ahmed Güner Sayar. A. Süheyl Unver Bibliografyasi, İşaret Yayınları, İstanbul, 1998.

7. Nuran Yıldırım, Yeşim Işıl UIman. The past and present of medical history and ethics (deontology) teaching at Istanbul University. 37 Uluslararası Tıp Tarihi Kongresi Bildiri Kitabı )10-15 Eylül 2000: Texas (ABD)2000, s. 238-243.

8. Türk Tarih Kurumu [Electronic resource]. URL.:http://www.ttk.gov.tr (date of resort 16.02.2017)

9. Türk Tıp Etiği ve Tıp Hukuku Araştırmaları Yıllığı. Ekim 2011-2012-2013. Vol. 45-6. Nobel Matbaacılık, Hadımköy-İstanbul.

10. Türk Tıp Tarih Kurumu [Electronic resource]. URL. http://www.tttk.org.tr (date of resort 16.02.2017)

11. Баскаков Н.А. Введение в изучение тюркских языков. М., 1962.

12. Гаджиева Н.3. К вопросу о классификации тюркских языков и диалектов // Теоретические основы классификации языков мира. М., 1980.

13. Кононов А.Н. Грамматика турецкого языка. М.Л., 1941.

14. Нистен Пьер Юбер [Электронный ресурc] URL.: http://www.people.su/80763 (дата обращения 16.02.2017)

\section{References}

1. Ahmed Güner Sayar. A. Süheyl Unver, Hayatı, Sahsiyeti ve Eserleri 1898-1986, Eren Yayıncılık, İstanbul, 1994.

2. Ali Haydar Bayat. Tıp Tarihi. Pınarbaş Matbaacılık Ltd. Şti., Istanbul, 2016.

3. Celal Saraç.Salih Zeki Bey. Hayatı ve Eserleri. Ed. Yesim İsil Ulman, İstanbul, Kizil Elma Yay. 2001.

4. Değer M. Dr. Galip Ata Ataç ve Tıp tarihine hizmetleri.ll Türk ve Tıp tarihi kongresi. Kongreye sunulan bildililer, İstanbul, 20-21 Eylül 1990. Türk Tarih Kurumu Yayınları.

5. Gülay Yıldırım, Selim Kadıoğlu, IIlter Uzel.Galip Ata Ataç`ın «Tıp Fakültesi» kitabında yer alan Osmanlı Dönemi Tıp Eğitimi tarihçesi bilgileri. Cumhuriyet Üniversitesi. Tıp Fakültesi dergisi 29 (4), 2007, s. 185-191.

6. Gülbün Mesara, Aykut Kazancıgil, Ahmed Güner Sayar. A. Süheyl Unver Bibliografyasi, İşaret Yayınları, İstanbul, 1998.

7. Nuran Yıldırım, Yeşim Işıl Ulman. The past and present of medical history and ethics (deontology) teaching at Istanbul University. 37 Uluslararası Tıp Tarihi Kongresi Bildiri Kitabı )10-15 Eylül 2000: Texas (ABD)2000, s. 238-243.

8. Türk Tarih Kurumu [Electronic resource]. URL.:http://www.ttk.gov.tr (date of resort 16.02.2017)

9. Türk Tıp Etiği ve Tıp Hukuku Araştırmaları Yıllığı. Ekim 2011-2012-2013. Vol. 45-6. Nobel Matbaacılık, Hadımköy-İstanbul.

10. Türk Tıp Tarih Kurumu [Electronic resource]. URL. http://www.tttk.org.tr (date of resort 16.02.2017) 
11. Baskakov N.A. Introduction into Turkic languages education. M., 1962.

12. Gadzhieva N.Z. To the question of the Turkic languages and dialects classification // Theoretical bases of the world languages classification. M., 1980.

13. Kononov A.N. The Turkish language grammar. M.L., 1941.

14. Nisten Pier Yuber [Electronic resource] URL.: http://www.people.su/80763 (date of issue 16.02.2017)

January, 12, 2017 